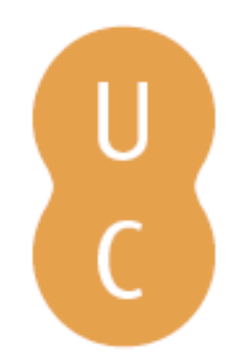

\title{
pompalina
}

\section{Incest: medical-legal perspectives}

Autor(es): $\quad$ Farina, G.; Sciarabba, C.; Stefano, E. Di; Argo, A.; Procaccianti, P.

Publicado por: Imprensa da Universidade de Coimbra; International Academy of Legal

URL

persistente: URI:http://hdl.handle.net/10316.2/31811

DOI: $\quad$ DOI:http://dx.doi.org/10.14195/978-989-26-0173-1_39

Accessed : $\quad$ 26-Apr-2023 14:44:33

A navegação consulta e descarregamento dos títulos inseridos nas Bibliotecas Digitais UC Digitalis, UC Pombalina e UC Impactum, pressupõem a aceitação plena e sem reservas dos Termos e Condições de Uso destas Bibliotecas Digitais, disponíveis em https://digitalis.uc.pt/pt-pt/termos.

Conforme exposto nos referidos Termos e Condições de Uso, o descarregamento de títulos de acesso restrito requer uma licença válida de autorização devendo o utilizador aceder ao(s) documento(s) a partir de um endereço de IP da instituição detentora da supramencionada licença.

Ao utilizador é apenas permitido o descarregamento para uso pessoal, pelo que o emprego do(s) título(s) descarregado(s) para outro fim, designadamente comercial, carece de autorização do respetivo autor ou editor da obra.

Na medida em que todas as obras da UC Digitalis se encontram protegidas pelo Código do Direito de Autor e Direitos Conexos e demais legislação aplicável, toda a cópia, parcial ou total, deste documento, nos casos em que é legalmente admitida, deverá conter ou fazer-se acompanhar por este aviso.

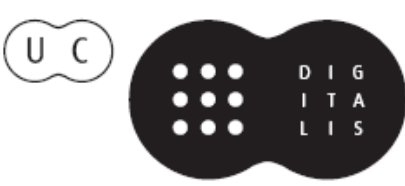




\section{Duarte Nuno Vieira Anthony Busuttil \\ Denis Cusack • Philip Beth}
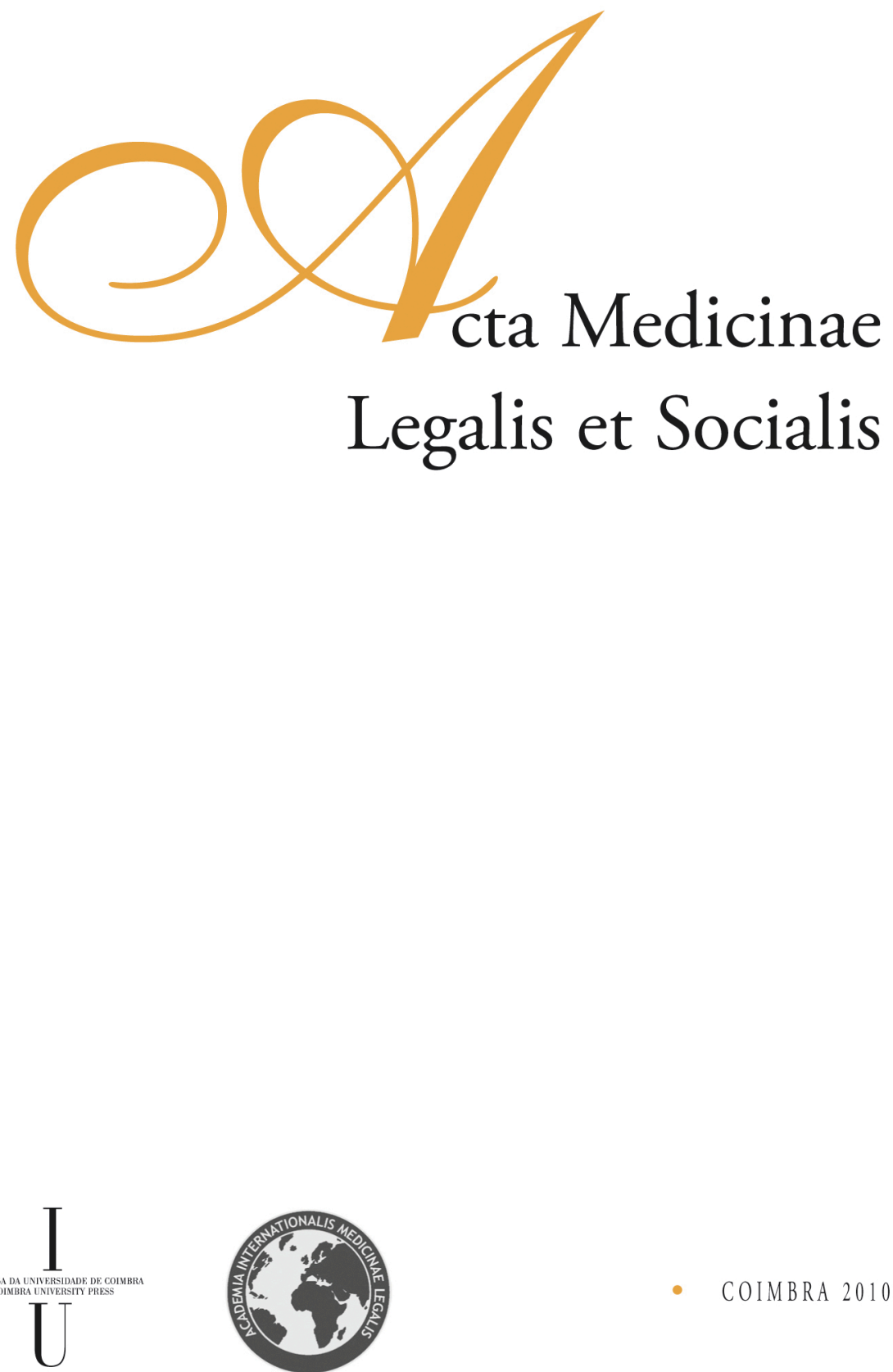


\author{
G. Farina, C. Sciarabba, E. Di Stefano, A. Argo, P. Procaccianti \\ Institute of Legal Medicine, University of Palermo, Palermo, Italy
}

\title{
INCEST: MEDICAL-LEGAL PERSPECTIVES
}

\begin{abstract}
Incest is a well-known phenomenon, defined as a sexual relationship between close blood relatives, usually between father-daughter, uncle-nephew and also brother-sister, or, in its broader sense, between a child and a stepparent or stepsibling.

Incest is a taboo in many countries; however incest and sexual aggression toward minors are not classified as a criminal behaviour in all part of the world.

Our study has the purpose to examine the legislator's attitude towards this social phenomenon in expansion. Clinical Forensic approach to this phenomenon in literature is an essential contributory to explain the physical and psychological consequences; but it is yet certainly possible to ameliorate legal-medical procedures of investigation. We report the laws in force in different countries so to appraise the exact connotation of this crime in our country.

The aim of this research is to take widest consciousness of the diffusion of this phenomenon in the health professionals and the difference of cultural approach in legal perspectives.
\end{abstract}

\section{Introduction}

Our study starts from the consideration that often the victim of incest becomes sexual abuser. The turn of the potential victim in executioner was not sufficient to urge the scientific community to the analysis and to the definition of treatment in favor of abusers. The therapeutic intervention on abusers is not practiced, perhaps, because of the social disapproval that this crime creates in each of us and which ultimately also affect the look of science. Our research, similarly to the Swiss experience, is going to organize efficient multi-professional strategies for early intervention that would build a model of effective treatment to stop the "cycle of abuse". Our project wants to provide, over time, an active contribution to the many professionals who deal with these subjects.

To achieve this aim we should also evaluate the different design of this crime in different countries of the world, in order to structure a protocol of care that is acceptable abroad. In fact, incest is a taboo in many countries; however incest and sexual aggression toward minors are not classified as a criminal behaviour in all part of the world. 


\section{Materials and Methods}

The adoption of standardized procedures, shared by the various health professionals involved, can simplify the management of incest victim, pointing to further interdisciplinary integrated approach to the victims. It can also improve the public debate inherent how politicians and leaders of multidisciplinary public centres should prioritise these endeavours.

But we must also consider that with the more and more consistent melting pot of populations, people with different cultures are in contact; this fact can lead to the realization of incest, according to the conception of the host Country, that are not so intended by people who committes them. Seems clear that in implementing the project we realized we must take into account the different environmental, cultural and psychological substrates as the criminal event was realized.

\section{Results}

From investigations carried out in Italy we have seen that in $90 \%$ of cases the abuse takes place in the family and the rapist is a certain frequency with the same father or stepfather.

In Italy there are almost 3000 cases of incest the year, or 6 per 100,000 people.

Incest usually occurs within families with low socio-economic status.

Studies showed a clear dominance of the father-daughter relationship, or the increasing involvement of the man who within the family plays in fact a fatherly role, although not linked to the victim by a relationship of consanguinity (paraincest); a few were, however, cases of incest between siblings or between parent and child.

The authors of incest usually have the following characteristics:

- age between 40 and 50 years;

- violent personality and behavior, often with previous criminal convictions or being alcohol abusers or with psychiatric disorders;

- extremely low level of education;

- lack of stable employment.

The victims of incest, instead, present in most cases the following profile:

- age between 11 and 15 years;

- $1 / 5$ of the sample is represented by individuals with serious psychological and intellectual problems;

- for children under 10 years old, the acts of lust outweigh; for teenagers, instead, rape is more frequent (study conducted by the Maternal Child Services at the Health Authority of the City of Genoa).

Various studies conducted, showed also a tendency to cyclicality of the crime of incest in successive generations of one family: the abused becomes in turn abuser ("cycle of abuse"). 
The incestuous relationship may cause to minors severe mental disorders and especially mental development, alteration in the development of character and serious sensibility disorders.

The most frequently disorders described in literature are:

- psychosomatic disorders and neurotic reactions;

- depression and attempted suicides;

- attempts to escape, and wandering;

- psycho-sexual disorders such as frigidity, homosexuality and promiscuity;

- feelings of guilt.

\section{Discussion}

Our study has, firstly, the purpose to examine the legislator's attitude towards this social phenomenon that is in expansion or, sometimes, becomes a spectacular media phenomenon, as recent judicial events in Austria. Clinical Forensic approach to this phenomenon in literature is an essential contributory to explain the physical and psychological consequences; but it is yet certainly possible to ameliorate legalmedical procedures of investigation. We report now the rules in different countries so to appraise the exact connotation of this crime in our country.

The incest, by definition, is not the simple performance of sexual acts of any kind, but it is consumed only with the completion of sexual intercourse. However, there is also who considers sufficient acts of sexual nature, even different than physical connection from the persons specified, so that resulting public scandal.

It is complex the predictability of competition between sexual violence (art. 609 bis) and incest (art. $564 \mathrm{cp}$ ). To examine whether sexual violence contributes with incest it is necessary to reintroduce the distinction between conjunction and carnal sexual acts other than this, in spite of the "unification" between the figures for rape and acts of violent lust provided for the new law. This is perhaps a lack of legislative attention to issues of sexual violence or an inability to coordinate between the rules of the Criminal Code; the competition between the crimes in question can not, in fact, matter in court by a differentiation which is considered culturally and legally separate.

The psychological element of the offense is the "general intent", then there must be both aware of the existence of the bond between the authors of the fact (it's just a bond of filiation illegitimate as long known to the authors) and the knowledge and desire to have sexual intercourse with a person referred to specifically in art. $564 \mathrm{cp}$.

The Italian Penal Code establishes (ex art. 564) the imprisonment for one to five years against everyone who commits incest with a descendant or an ancestor, or with a close relative, or with a brother or sister, so that it arouses a public scandal. Just the simple notion of "public scandal" is the objective condition of punishment. Incest instead, as a form of sexual abuse, as physical and psychological constriction to do, or to undergo, actions against one's own will, is a penal crime according to Law $\mathrm{n}$. 66/1996 ("Norme contro la violenza sessuale" - "Rules against sexual violence"). Every "imposed" incestuous relationship is not a simple "incest" but the worst hypothesis of "sexual violence". In these cases incest has to be considered "aggravation" of the crime of sexual violence. 
Unlike in Italy, in France as in Belgium, the laws that condemn incest were abolished by Napoleon. In Spain this offense has been decriminalized, but the marriage between blood relatives is not yet possible, and Sweden, however, is the only country in Europe which allows marriage between siblings who share only one parent. In New Jersey there is no penalty for the majority, while in Massachusetts it is expected to imprisonment up to twenty years for sexual activity with a closer relative of the cousin of First Instance. In Japan, incest is legal (the law that condemned him was abolished in 1881), although generally regarded as immoral, and, however, consanguineous can not marry. In Israel, incest between consenting persons who have both completed the age of majority is not a crime while it is punished the incestuous relationship with a minor. In Brazil, finally, the law allows incest only in certain cases, that is uncle and nephew can have a relationship, but on condition that they firstly are subjected to genetic control.

From what emerged from our study we can see that incest does not exist as a criminal case in all Countries; in some of these, in fact, you can marry even if blood relatives: the prerequisite is the consent between the parties. It becomes clear that the term incest is better and more specifically referred to cases where there is a violent relationship, in which one party is forced to suffer abuse or is too weak, even from a psychological point of view, to oppose a good resistance. This does not occur in Germany, where the union between close relatives has always prevented, even when aware and consenting adults, which in light of the current legislation, that is part of the old policy of "racial hygiene" promoted by the Nazis and still in force.

\section{Conclusions}

The aim of our contribution is to take widest awareness of the diffusion of this phenomenon among health-professionals perspective and differences of cultural approach in legal views.

When physical, sexual and psychological abuses on children take on the contours of incest, offense is even more serious and even the risk of the phenomenon of the cycle of abuse is more concrete. The early identification of a victim is inescapable obligation of all the professions of experts, really competent to provide support only if properly trained for this purpose. Improving the professional interdisciplinary abilities in this field of person abuse can help victimes.

\section{References}

CELBIS O., OZCAN M.E., ÖZDEMIR B., Paternal and sibling incest: A case report, Journal of Clinical Forensic Medicine 13, 37-40, 2006.

LAKIÈ A, PEJOVIC MM. "Incestuous Family" - Adequacy of model for clinical practice (Case Report), Clinic for neurology and psychiatry for children and adolescents.

ROMAIN-GLASSEY N., ANSERMET C., HOFNER M.C., et Al., L'unité de médecine des violences: une consultation médicolégale assurée par des infirmières, Médecine \& Droit, 95, 58-61, 2009.

ITALIAN PENAL CODE. 